these experiments suggest that a particular period exists around the 30 th and 6oth day of life of piglets having passive immunity. During this period, maternal passive immunity protects piglets against virulent infections, but also allows induction of active immunity following vaccination with live vaccine. New investigations are needed to determine limits and characteristics of this period.

\title{
Immune response in piglets. The effect of speeific passive immunity on immune response against an inert antigen, hen egg-white lysozyme
}

\author{
P. ROUZE, M. HOUDAYER and J. J. METZGER* \\ Laboratoive de Pathologie Porcine, I. N. R. A., \\ y8850 Thiverval-Grignon \\ * Station d'Immunologie et de Virologie
}

In previous reports, we already showed that piglets have been actively immunized with lysozyme in the presence of specific antibodies acquired by the colostral way or by intraperitoneal injection. The purpose of this new cxperiment, realized without any adjuvant was to study the role of this parameter. In these conditions the injection of increasing doses of lysozyme, even in the absence of any specific antibody, stimulated a less efficient immunization. This active immunity was inhibited by rather low passive antiborly amounts. This result led us to define the passive antibody threshold beyond which lysozyme antigenic stimulation was ineffective and to show that its level was lowered in the absence of adjuvant. In this paper, the practical implication of this threshold concept is discussed.

In the same experiment, we compared the effect of the stimulation with a living and an inert antigen, namely hog-cholera virus vaccine and lysozyme, in passively immune animals. We observed a narrow parallelism between these two systems. It appeared, at last, that the challenge performed with the fully virulent Alfort strain of Swine fever virus led to an immunodepression which tends to be suppressed by the vaccination.

\section{Respiratory disease syndroms in the young pig. Pathogenic properties of Ascaris suum}

\author{
J. P. RAYNAUD, A BOUCHET and G. BRUNAULT \\ Station de Recherches et Développement vétérinaire, \\ Pfizer International, \\ B. P. 42, 37400 Amboise (France)
}

The pathogenic properties of $A$ scaris suttm were checked on mice and an attempt was made to determine the dose which given to swine is not able to cause any rise in the blood level of eosinophilic cells.

- Embryonated eggs can easily give respiratory symptoms in young pigs of $15 \mathrm{~kg}$ b.w. Even 
a strain of embryonated eggs isolated from faeces gave symptoms at a very low level : I ooo eggs/ pig.

- 25 strains isolated in our area were not really pathogenic if pulmonary lesions on mice are the criteria (BROWN and CHAX).

- Strains isolated from faeces are ineffective on mice, but highly pathogenic on swine. They could be considered as more harmful for swine than those coming from dissection or from laying, but cannot be selected on mice.

- It is necessary to give less than 500 eggs/piglet if the eosinophilic reaction has to be avoided. For high numbers this reaction is strong, but short in time.

In contrast with natural infestation so easy to bring about by mere cleterioration of the hygienic conditions, experimental infestation is difficult to obtain as the parasites go through the small intestine and donat remain inside this organ at a regular level.

However, liver or lung passage is quite easy to control and manage.

\title{
Swine gastro-intestinal parasites in France. Contribution to the epidemiology of Hyostrongylus rubidus after worm counts in adult sows and boars at the Slaughter-House
}

\author{
J. P. RAYNAUD \\ Station de Recherches et Développement vétérinaire, \\ Pfizer International, \\ B. P. 42,3r400 Amboise (France)
}

Stomach parasites and egg counts in adult sows and boars from family breedings and small size units were controlled.

Among 4075 stomachs examined, 27.9 P. 100 (I I 37) were found with worms. Out of 33 animals with parasites in the stomach, egg counts were important for Ascaris, Oesophagostomum and Hyostrongylus.

For an average of 573 Hyostrongylus eggs/gramme an average of 64 66 I Hyostrongylus including $4^{1} 6 I_{4}$ adults (values from 360 to 205600 ) was found in the stomach. Those figures are considerable.

\section{Homocytotropic antibodies in the pig}

\author{
J. J. METZGER, P. ROLZE, Ch. BOURDIEU and MI. HOUDAYER
}

Laboratoire de Pathologie porcine, I. N. R. A.,

78850 Thiverval-Grignon

Immunization of pigs with hen egg-white lysozyme in the presence of complete Freund's adjuvant gives rise to homocytotropic antibodies the kinetics of which parallel those of early antibodies. Through gel-filtration, however, those reaginic antibodies bchaved as $7 \mathrm{~S}$ molecules. 